\title{
Beyond Insurgency to Radical Social Change: The New Situation ${ }^{1}$
}

\author{
JOHN FORAN \\ University of California, Santa Barbara, USA
}

ABstRACt The Arab Spring and U.S. Occupy movements surprised the world in 2011, showing that movements for radical social change remain viable responses to the intertwined crises of globalization: economic precarity, political disenchantment, rampant inequality, and the long-term fuse of potentially catastrophic climate change. These movements possess political cultural affinities of emotion, historical memory, and oppositional and creative discourses with each other and with a chain of movements that have gathered renewed momentum and relevance as neoliberal globalization runs up against the consequences of its own rapaciousness.

Three paths to radical social change have emerged that differ from the hierarchical revolutionary movements of the twentieth century: 1) the electoral path to power pursued by the Latin American Pink Tide nations, 2) the route of re-making power at the local level or seeking change at the global level, both by-passing the traditional goal of taking state power, and 3) the occupation of public space to force out tyrants, as in Tunisia and Egypt.

This paper assesses the strengths and limitations of each path, arguing that social movements and progressive parties together may possess the best chances for making radical social change in this new situation. These threads of resistance may also point toward a future of radical social change as we imagine their enduring results, selfevident and more subtle.

"If Egypt could get rid of Mubarak, Wisconsin can get rid of Walker!" John Nichols, in Uprising, tells of a demonstrator in Madison who was holding up this sign on a cold February night in 2011, the words written in Arabic. When he asked the man how he had come to know Arabic, he said, "I don't. I had it translated on Google last night." Nichols comments that when a middleaged unionized American is inspired enough by the Arab Spring to use the 
internet to translate a slogan for his struggle in Wisconsin into Arabic, then something is going on (Nichols, 2012). And something is indeed going on. Egyptian activist Maor Eletrebi sent a letter to Wisconsin, in which he wrote: "The beauty of Tahrir Square you can have everywhere, on any corner, in any city, or in your heart.... Breathe deep, Wisconsin, because justice is in the air" (quoted in Nichols, 2012, p. 1). Later in the year, when Adbusters called for an occupation of Wall Street, they asked "Are you ready for a Tahrir moment?" (Adbusters, 2011).

Radical social change, in the sense of a deep transformation of a society, community, region, or the whole world in the direction of greater economic equality and political participation, and accomplished by the actions of a strong and diverse popular movement, is clearly in the air we now breathe. The signs are everywhere: the events of 2011 were of a world-historical order. The Arab Spring brought the overthrow of dictators by non-violent mass popular resistance in Tunisia and Egypt, by force of arms in Libya, with Syria in agony (and by the time you read this?), and with the courageous stands of ordinary people in the streets of Bahrain, Yemen, and elsewhere. The Occupy Wall Street movement seemed to come out of nowhere six months later, and morphed with astonishing speed into like-minded occupations in hundreds of U.S. cities within six weeks. Just before and after 2011, we also witnessed the indignados' revolt in Spain, student protests in Santiago, London, and Quebec, street demonstrations and battles in England and Greece, movements around corruption in India and housing in Israel, striking miners in South Africa, Pussy Riot in Russia, and workers wild-catting and communities fighting pollution across China, and finally, the American Autumn of Occupy Wall Street. In mid-2013, Egyptians took to the streets again to oust their one-year old Morsi government, citizens protested throughout Brazil at the high cost of buses and the Olympics, and the occupation of a park in central Istanbul by a few green activists brought thousands out to protest the authoritarianism of their government. Though state power was taken only in Tunisia and Egypt, the breathtaking scale and speed of events marked 2011 as one of the most militant years in the history of radical social change. Something is indeed going on.

Explosions of change always raise the question: Where do they come from? It looks like these dramatic events just happen. But there is always a history, and a context. Their global sweep affirms the need for what Hamid Dabashi (2012) has termed a "liberation geography," and leads to another question: Are these events connected? What - if any - threads of affinity do they share, and what explains their simultaneity and common sensibilities? We are witnessing the rise and articulation of new political cultures of opposition and creation on a global scale, not altogether unprecedented but very different from those that inspired the great social revolutions of the twentieth century. And these changes may also point towards future prospects as we try to imagine their enduring results and impacts - self-evident and more subtle. It seems likely that these will be many, widespread, and long-lasting, no matter what happens in the next election or at the next public confrontation. 


\section{Political Cultures of Opposition as the Threads of Creation}

In Taking Power: On the Origins of Revolutions in the Third World (Foran, 2005), I proposed a hypothesis about the origins of revolutions that brought together the economic and social dislocations of dependent capitalist development, the political vulnerabilities of dictatorships (and, paradoxically, of truly open polities where the left could come to power through elections), and a conjunctural economic downturn accompanied by a favorable moment in the world system where leading outside powers did not (or could not) intervene. Looking at the world since 2009, we see versions of each of these: the glaring contradictions of neo-liberal capitalist globalization, the persistence of personalist regimes (especially in the Arab world) and wide disenchantment at the hollowing out of representative democracies in Europe, North America, and Latin America, the deepest and most dangerous global economic downturn since the 1930s, and finally, the attenuation of U.S. power due to the military occupations of Iraq and Afghanistan, growing public debt, the rise of Asian economic centers, and the financial bubbles that brought on the great recession.

In the twentieth century, when all of these more or less structural conditions presented themselves, the final, requisite piece for fundamental social change was one of agency and culture: the ability of revolutionaries and ordinary citizens to fashion powerful political cultures of opposition capable of bringing diverse social groups to the side of a movement for deep social change, as happened in the Mexican, Russian, Chinese, Cuban, Nicaraguan, and Iranian revolutions. It should be noted that there are also political cultures of legitimation that states draw on, and that these can fray for many reasons, so that in a Gramscian sense there are always multiple political cultures on both sides of a particular state/civil society divide, whose proponents constantly maneuver for position, and ultimately for hegemony.

The origins of radical political cultures lie in the experiences of people, in the subjective but shared emotions and dynamics that animate their daily lives and colour their politics. At the same time, revolutionary discourses, in the form of consciously articulated ideologies - such as socialism, nationalism, democracy, or radical interpretations of religion in the twentieth centurytravel from revolutionary groups into local settings, as well as circulate between revolutions. Meanwhile, historical memory, cultural experience, and "idioms" or folk understandings also circulate in communities, putting people's concerns in everyday terms such as fairness, justice, dignity, or freedom, or as concretely as "Bread, land, and liberty," "Death to the Shah," or "Patria libre o muerte!"

In any society, there may exist more than one political culture of opposition, for people don't necessarily share the same experiences, speak the same idioms, or respond to the same formal ideologies. The most effective revolutionary movements of history have found ways of tapping into whatever political cultures emerge in their society, often through the creation of a common goal - "the regime must step down" or "the foreign 


\section{John Foran}

powers must leave." When this happens, a radical or revolutionary movement can gain enough committed followers to take power when other favourable conditions are present. The forging of a strong and vibrant political culture of opposition is thus an accomplishment, carried through by the actions of many people, and, like revolutions themselves, is relatively rare in human history.

It now appears clear that the political cultures of opposition that enabled the great social and anti-colonial revolutions of the twentieth century are being transformed in new directions. What we might term the "old" or classical cultures of revolution typically featured armed insurgents who directly engaged the state and its military, though they were aided in all cases by nonarmed groups and organizations who provided crucial support activities of many kinds [see figure 1].

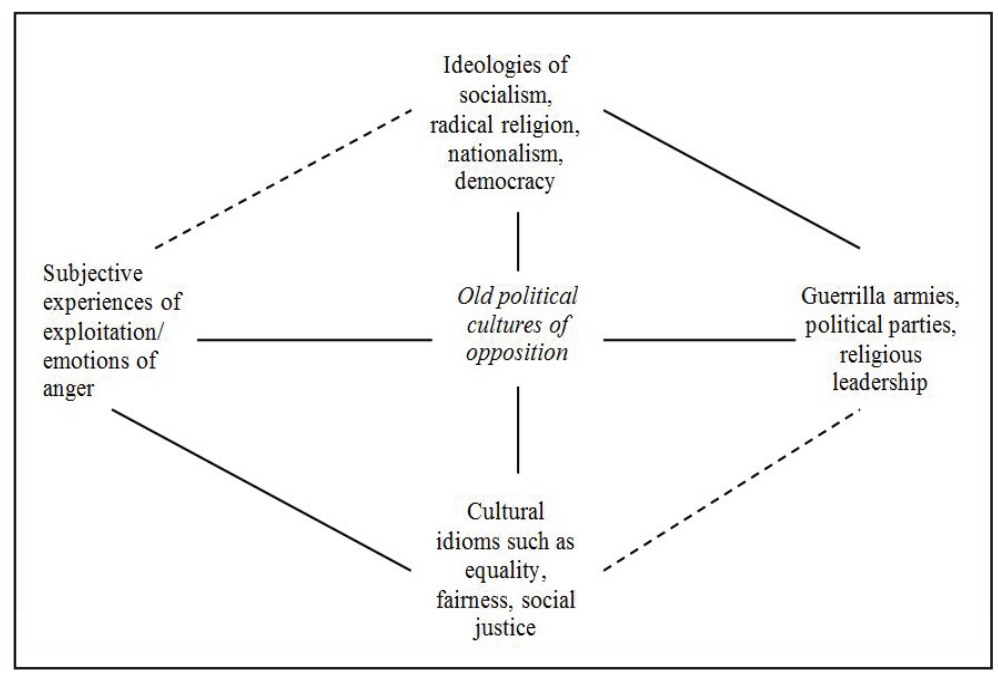

Figure 1 The making of "old" political cultures of opposition in the Mexican, Russian, Chinese, Cuban, Iranian, and Nicaraguan revolutions

In Russia and China, and more loosely in Nicaragua and Cuba, socialist political parties existed alongside the revolutionary armies and gave direction to them. In Iran, the network of mosques and clerics provided the organizational base for the mass demonstrations and general strike that undermined the shah's government without taking up arms. A common thread across cases is the hierarchical structure of the movements, with well-identified individuals at their head-Emiliano Zapata and Pancho Villa, Lenin and Trotsky, Mao Tse-Tung, Fidel Castro and Che Guevara, Khomeini, and the somewhat less famous Sandinista leadership of the Ortega brothers. The hierarchical nature of guerrilla militaries, socialist parties, and religious leadership meant that influential figures - always male, and often privileged in background - would lead in the name of the people. All of this was equally 
true of the great anti-colonial revolutions in Vietnam, Algeria, Angola, Mozambique, and Rhodesia/Zimbabwe.

These political cultures produced broad and powerful revolutionary movements, defeating highly militarized states with powerful external backers (usually, in fact, the United States). Once in power, however, they too often fragmented, as different groups had their own aims, and the common bonds that had united them all proved fragile and difficult to sustain. I am not suggesting that the limitations of these revolutions can be laid entirely at the feet of the political cultures that made them - far from it. Of substantial weight in the outcomes of each were other factors that acted independently of political culture and human agency: external intervention and disadvantageous positions in the world-economy chief among them. But the possibility remains that despite the strength and solidity of these revolutionary political cultures, so indispensable in overthrowing the states they opposed, they still possessed features - especially the combination of the leaderships' emphases on formal ideology over popular idiom, and the hierarchical nature of the organizations that came to power-which must be counted among the Achilles heels that led to the disappointing and limited outcomes that followed.

In the twenty-first century, the nature of movements for what we might now call radical social change rather than revolution has itself changed, as activists, reformers, dreamers, and revolutionaries globally have pursued nonviolent paths to a better world, intending to live and act as they would like that world to be. That is, the ends of justice are no longer held to justify the means of violence, but the means of non-violent resistance reflect and guarantee the ends that they seek. In this, they embody and illustrate the virtues of "prefigurative politics" (Polletta, 2002) and in particular, horizontalist ways to realize them (Sitrin, 2006, 2012; Zibechi, 2010).

I have recently begun to call these positive, alternative visions "political cultures of creation" (Foran, 2013). Movements become even stronger when to a widely felt culture of opposition and resistance they add a positive vision of a better world, an alternative to strive for to improve or replace what exists. In this sense, some of the differences between old and new movements for radical social change seem to include the attempt to get away from the hierarchical organizations that made the great revolutions and move in the direction of more horizontal, deeply democratic relations among participants; the expressive power of using popular idioms more than ideological discourses; the growing use of nonviolence; and the salience of political cultures of creation alongside political cultures of opposition and resistance. [see figure 2]. 


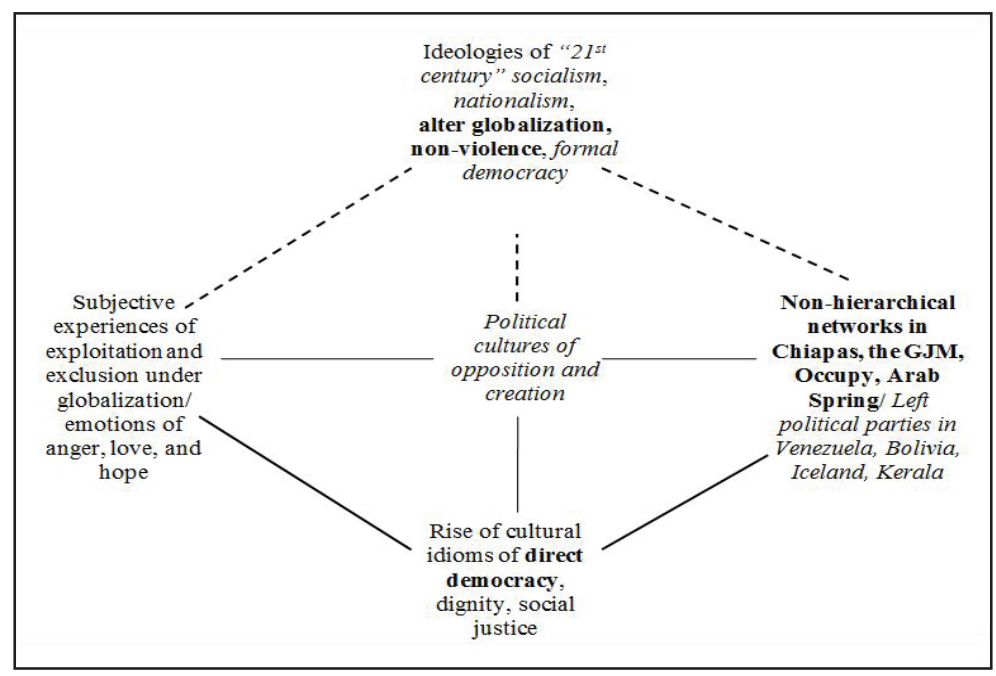

Figure 2 The emergence of "new" political cultures of opposition and creation in the twenty-first century (dotted lines indicate relationships that are more loosely connected): the Zapatistas and the Global Justice Movement are bolded so as to stand out from the italicized Pink Tide of elected left governments in Latin America, with commonalities in plain text

To the century-old problem posed by Lenin-who is not a particular favorite of the movements under discussion - "What is to be done?"2 (at least he got the question right!), social movements in the last decade of the twentieth century and the first dozen years of the present one have been offering some strikingly new and interesting answers.

Two distinct and rather different paths to change have been pitted against each other by scholars and practiced by participants on the ground: the electoral path to state power being pursued by the elected left-of-center governments of the Latin American "Pink Tide," most radically in Venezuela, Ecuador, and Bolivia, and the opposite route of turning one's back on state power, and instead carving out autonomous spaces both below it at the level of the community as the Zapatistas and Occupy are doing, or above it, as the global justice movement and global climate activists have sought to do. The Arab Spring opens up a third new path, starting with massive non-violent direct action and following up with a protracted struggle for new democratic institutions. All of these paths can be distinguished from what came before, not least in the new political cultures that have attracted people to them.

\section{Global Affinities}

Precursors. It may be that the first harbinger of the new movements was the events of May 1968 in France. As in 2011, they seemed to come out of nowhere, and grew with an unprecedented intensity and speed from small 
actions into a wave of revolt, involving occupations of schools and factories, demonstrations and direct action in the cobble-stoned streets of Paris, democratic, open debate with participation for everyone with something to say, and a massive general strike. The movement's tactics grew out of a vision of a different mode of everyday life, of a new community that would be personally liberating and empowering. It presaged a world of direct, participatory democracy, on as large a scale as possible. In its best moments, "many people, not only students, but old and young, men and women, intellectuals and workers, the specialized and the unskilled, spoke simply about what shape the world should take, what should they do and be, what life should be like" (Poster, 1975, p. 385). It set a high standard for political cultures of creation, and marked a new departure in the culture of movements for radical social change.

Yet, with no agreed-upon common demands or goals, and no organized political outlet, the forging of a political culture strong enough and effective enough to hold together the disparate parts of the movement eluded them; by mid-June the movement seemingly vanished into thin air as suddenly and surprisingly as it had appeared.

Or did it? Though the protests around the world in 1968 ended in defeats almost everywhere-perhaps most consequentially in France, Czechoslovakia, and Mexico - they created significant political and cultural legacies of protest which have come down to us in the form of new social movements today. As Cohn-Bendit told Paris-Match: "A different world is going to be made over" (quoted in Labro et al., 1969, p. 53). This is a remarkable prefiguring of the global justice movement's famous slogan a generation later: "Another world is possible." And as Immanuel Wallerstein observed: "The spirit of 1968 flows through [the] Arab Spring and [the] Occupy Movement" (Wallerstein, 2011). The May and other global protests of 1968 marked the beginnings of something new, and their most striking feature may well have been their vibrant political cultures of creation.

Another twentieth-century precursor followed close on the students' heels when Chilean socialist Salvador Allende led the Popular Unity coalition to power with a slim plurality in the 1970 elections and began to construct what his supporters called "the Chilean path to socialism" through legal, constitutional means and with massive popular enthusiasm and support, departing sharply from the armed struggle path to power of previous revolutions, and achieving a share of state power that had eluded the explosion in France. The political cultures of Chile's left and centrist social forces - perhaps two-thirds of the population-initially presented a lively, varied panorama of social justice-oriented, class-conscious, and articulate reformers and democratic revolutionaries. But in the vise tightened by U.S. economic and political destabilization, Chilean society polarized politically. The democratic center and the democratic left lost confidence in each other, and in their own capacity for unity (see the accounts in Cooper, 2001; Spence, 1978; Valenzuela, 1979). When the military seized power on September 11, 1973, the dictatorship that followed and the world's first neo- 
liberal economic model condemned Chileans to a reign of terror and loss. Chileans would restore their fragile democracy only fifteen years later, after numerous demonstrations, through a decisive repudiation of Pinochet at the polls.

The Allende years represent an incalculably precious missed opportunity for the transformation of society through democratic means. Many observers at the time argued that revolutionary democratic paths to a better world were doomed by internal contradictions and powerful counter-revolutionary intervention, and the experiences of the Grenadian and Sandinista revolutions in the 1980s reinforced this view. Yet a quarter century later, the experiences of the Pink Tide governments in Latin America suggest that the Chilean path to socialism contains more positive lessons, with Venezuela, Bolivia, and Ecuador pursuing a "twenty-first century socialism" that is democratic and original, reminding us that flexibility and imagination should temper historical analysis and political action itself.

A democratic socialism for the twenty-first century in Latin America. In the late 1990s a democratic route to radical social change unfolded throughout much of Latin America, most vigorously in the Venezuela of Hugo Chávez, first elected in 1998, and in Bolivia under its indigenous president Evo Morales, first elected in 2006. Chávez (who died in 2013) and his supporters have made gains in education, literacy, nutrition, and health care, with significant and growing popular participation among the poorer two-thirds of Venezuelan society, including residents of barrios and shanty towns, indigenous and Afro-Venezuelan people, women, and workers.

In both Bolivia and Venezuela there has been far less emphasis on an ideological appeal to socialism by the leaderships of these elected left-ofcenter governments, and in its place we find an upsurge in new, popular conceptions of social justice. In fact, Chávez coined the term " $21^{\text {st }}$-century socialism" precisely to emphasize its democratic roots in the Allende and post-1979 Sandinista experiences. When asked what he understood by "socialism," Evo Morales, the president of Bolivia, replied: "To live in community and equality.... It is an economic model based on solidarity, reciprocity, community, and consensus. Because, for us, democracy is a consensus.... And beyond that, [it means] respecting Mother Earth, the Pacha Mama" (quoted in Dieterich, 2006).

Felipe Quispe, an Aymara indigenous leader who is critical of all politicians, including Morales, adds to this a strand of nationalism: "The foreigners can stay as long as we get 90 percent of the power. If not, there will be war... We will rewrite history with our own blood. There will be a new sun, and even the rocks and the trees will be happy" (quoted in Parenti, 2005, p. 18). Carlos Laime, a 33 year-old tailor, makes this connection: "I feel more Bolivian since an Aymara is in power. Now we can talk about majorities, and in [public] offices the people who are served are not only those wearing ties" (quoted in Manrique 2006, p. 8). For Morales, "if globalization does not admit difference and pluralism, it's a selective globalization, therefore it will be almost impossible to resolve environmental issues and save humanity.... So 
we're talking about a profound change in the economic models and systems" (Morales, 2007). Such a change will clearly draw on and require the embrace of new political cultures of creation by a wide coalition of people, differently located but imbued with some common desires and dreams of deeply radical social change.

Despite their differences, recent center-left governments of Brazil, Uruguay, Bolivia, Ecuador, El Salvador, Paraguay, Venezuela, Chile, and Argentina have all tapped into political cultures that differ markedly from the older revolutionary tradition, highlighting instead a democratic route to power and the effort to build a more participatory political system. The current of socialism is being reworked in new, more democratic directions in the post-Cold War era, and the depth of the democratic ideal is arguably proving a more solid barrier to external and internal intervention than in the more polarized era of the Allende experiment with this form of revolution in the 1970s. In looking at all of these cases together, we find a democratic route to power and the effort to build a more participatory political system on the parts of significant sectors of their populations.

"We Want a World in which Many Worlds Fit:" Re-Making the Nature of Power through Direct Action. Just before the emergence of the Pink Tide, the Zapatistas opened the twenty-first century on January 1, 1994, the same evening that the Mexican and U.S. governments were celebrating their North American Free Trade Agreement deal. Behind masks of anonymity they rose to visibility and issued an invitation to join them that resonated powerfully with the first stirrings of the global justice movement, which heard the call that "Another World is Possible." Zapatismo is not an ideology, but rather a new way of making radical change, embracing the vision of changing the world without taking power, as the title of John Holloway's 2002 book so aptly puts it, and instead attempting to remake the nature of power altogether. Here we are clearly in the presence of a new political culture of creation, expressed in stories, myths, dreams, and poetic narrative.

The encounter of the Western revolutionary tradition with indigenous values and practice in Chiapas has shaped the nature of radical social change to this day (Conant, 2010; Gunderson, 2013). Turning their backs on established ideologies, and drawing instead on their own political idioms, indigenous communities provided core Zapatista principles such as mandar obedeciendo (to rule by obeying), arguing that leaders should serve the community and struggle for its issues rather than the community existing to further the vision of the leadership. Another innovative Zapatista practice is suggested by the phrase dar su palabra (literally, to have one's say). The goal is to make decisions that benefit from the diverse insights of all present, thereby seeking solutions which have eluded them in the past. Such discussions can take much longer than formal debates followed by votes, but once decided they endow the group's choices with a broader legitimacy.

For Javier Eloriaga, "We have to do politics in a new way. You can't accept only what is possible because it will bring you into the hands of the system. This is a very difficult struggle. It is very, very difficult" (quoted 
in Dellacioppa, 2009, p. 73). Or Marcos: "Zapatismo is not an ideology. It is not a bought and paid for doctrine. It is an intuition" (Big Noise, 1998). Part of this involves "walking at a slower pace," acknowledging that change is a long and slow process, not secured with the mere seizure of power or electoral victories. Indeed, the Zapatistas have said that they do not aspire to take state power in the traditional sense, but rather, to create "a free and democratic space for political struggle" (quoted in Hayden, 2002, p. 226). They have inspired activism far beyond their own communities, drawing the emergent global justice movement to their 1996 "Intergalactic Encounter" against neoliberalism, and captured the imagination of North American and European youth (and a few sociology professors!), among many others.

The latter half of the 1990s witnessed the rise of a global justice movement, a "movement of movements" that achieved public visibility when a broad gathering of students, union activists, and environmentalists joined in civil disobedience and direct action to shut down the meetings of the World Trade Organization in Seattle in November 1999. If we focus especially on the political cultures of creation that animate the global justice movement, we can see some further novel features, many of them paralleling the Zapatista rebellion. On the subjective side of experience and emotion, it is useful to point out that love - of life, of people, of justice - often nurtures the vital force that impels ordinary people into extraordinary acts. Expressing hope and optimism, it provides a constructive counterpoint to those other powerful animating emotions, hatred and anger. To this, we may add the subjective experience of hope (is hope an emotion?), which offers people a positive vision of the future to counter feelings of hopelessness and despair. In the words of David Solnit, one of the organizers of the spectacular Seattle action of 1999: "Hope is key. If our organizations, analysis, visions and strategies are lanterns, then hope is the fuel that makes them burn bright and attracts people to them" (D. Solnit, 2004a). Hope and love sustain the emotional foundations of the new political cultures of creation, as attested in the 2013 film Occupy Love (Ripper).

As with the Zapatistas, we can also discern here a sharp turn toward popular ways of speaking over ideological texts. It should be observed that this rejection of ideology does not mean that these movements are "nonideological" so much as they are "anti-ideological," steeped in ideas and ideals even as they reject all "isms." This vision entails radically different modes of struggle for an age of globalization where the location of the enemy is the increasingly interlocked institutions of global capitalism in the form of the WTO, IMF, World Bank, transnational corporations, and Rich and Majority World states. Global justice activists have mixed old and new modes of struggle: sit-ins, boycotts, strikes, and occupations of land or factories with civil disobedience, occupations of schools and public spaces, world gatherings such as the World Social Forum (a prime site for the elaboration of political cultures of creation), web-based campaigns and networks of activists, the building of community-based institutions such as co-ops, people's kitchens, clinics, and a hundred other forms of direct action aimed at undermining and 
transforming the system rather than reproducing it. In a no doubt conscious echo of the Zapatistas, direct action organizer David Solnit writes: "The world cannot be changed for the better by taking power... Capturing positions of state power, either through elections or insurrection, misses the point that the aim of uprooting the system is to fundamentally change the relations of power at the root of our problems" (D. Solnit, 2004a, 2004b, xix). Occupy would emerge from and take a page from this movement.

Before this happened, however, the U.S. response to the September 11, 2001 terrorist attacks on New York's Twin Towers effected a large setback for projects of deep social change, militarizing the Clintonian course of globalization from above by a transnational elite and opening up a new and uncertain economic and geopolitical period. It also broke the growing momentum of the global justice movement with its "war on terrorism" discourse. It created horrifying facts on the ground in a shattered Iraq and Afghanistan that defy restitution, and conjured paralyzing new fears and amorphous threats in the United States where none existed before (Shadid, 2006). The cause of global justice was put on the defensive, forced to organize an anti-war movement, which in fact coordinated the largest antiwar demonstration ever on February 15, 2003, a month before the invasion. ${ }^{3}$ By 2006, the Bush administration had finally overplayed its hand, at home and abroad, stumbling in its prosecution of the war in Iraq, its response to Hurricane Katrina, the wire-tapping of its own citizens, its budget priorities and massive indebtedness, and its studied inaction on global warming and climate change, thereby giving renewed momentum to a movement that would eventually sow the seeds of Occupy.

\section{The New Political Cultures and 2011}

We arrive at last to the movements that shook the world in 2011. In January and March, long-entrenched dictators fell to popular uprisings in Tunis and Cairo, and newly elected political leaderships offered greater hope for positive social change than had existed in the region in decades. This came about through massive occupations of public space by broadly-based social forces that resolutely resisted state repression with non-violent, ongoing, and creative direct action ("civil disobedience" seems too mild a term for this). In both cases, and unlike elsewhere in the greater Arab Spring (Libya, Syria, and Bahrain), the regimes they faced and the armies that supported them gave way to popular demands and stepped aside. The U.S. scrambled from stubborn disbelief and compromise maneuvers to withdrawing its support for the "democratic dictatorships" of Zayn al-Abidine Ben Ali and Husni Mubarak, each of whom then ceded power. After these clear targets were sent into exile or prison, the movements faced the structural obstacles of old regimes of the economic and (especially in Egypt) military elites and quickly (in Tunisia) or slowly (in Egypt) pushed them into elections that cemented these non-violent political revolutions (Anderson, 2011, 2012). 
It is possible to make sense of these revolutions in terms of the patterns of the great revolutions of world history, and the model of social revolutions put forward in Taking Power. Namely, a political economy of dependent, neoliberal capitalist development sharpened the grievances of populations living with high and rising levels of unemployment, the highest in the world, in fact, for women and for youth under 25 (Achcar 2012; Beinin 2011, pp. 26-27; Goldstone 2011, p. 36). That this is a globalization story is suggested by the fact that it was the youth generation of 2010 that made the revolts, not that of 1990 at the dawn of globalization's effects in the region.

The regimes that ruled both countries were classic cases of the type of personalist dictatorship most vulnerable to revolutions historically: amassing riches while excluding the majority of the population from a meaningful vote and repressing dissidents ruthlessly. This meshing of the economic and political elite made the dictators in each case a clear target of popular wrath.

The conjunctural elements of revolutionary outbreaks were also present by the end of 2010: the effects of a teetering global economy on already desperate populations fueled the economic downturns (again, a question of timing: 2010, not 2007 before the crisis). The interconnectedness of global crises meant that one could "read the world in a loaf of bread," as Christian Parenti put it: the hot summer of 2010 devastated the Russian grain harvest, raising the cost of the Egyptian people's staple later in the fall and bringing many to the point of rebellion (Gelvin, 2012, pp. 21-23; Parenti, 2011).

The international conjuncture was also critical to the movements' success. This is most obvious in the case of Libya, where NATO's intervention stopped Qadhafi's counter-offensive just short of Benghazi, then crippled his air force and the movement of heavy armor out of Tripoli. In the cases of Egypt and Tunisia, the timing of the revolutions owed much to favourable turns in the world system: the events in Tunis moved so swiftly that neither France nor the United States could react to them before Ben Ali was gone, while in Egypt, the US wavered uncertainly in its support of Mubarak, and ultimately decided to cast him to the winds while trying to maintain its influence on the army, which wisely stood aside to protect its own interests and stay on the winning side. In Syria and Bahrain, rebels enjoyed no equivalent geopolitical opening.

In terms of the political cultures of opposition and creation that underlay the Arab Spring, we might comment first on an emotional aspect. As Mehran Kamrava (forthcoming) notes, the pillars of the ruling bargains born in the national liberation movements of the 1950s, "once sources of comfort and mass ebullition, now [were] comprised of fear, loathing, suspicion, and submission." When crowds poured into the central squares and roundabouts of Tunis, Cairo, Tripoli, and Manama, they broke this fear, and perhaps, with it, long-structured or assumed patterns of deference more generally.

It is also clear that the Arab Spring revolts were driven less by appeal to any ideology than by tapping into popular idioms of everyday concern. These were concentrated in the slogans chanted by crowds, in the first instance against the dictatorships: in Egypt, "We won't leave until he leaves" (Khalil, 
2011, p. 5). In Tunisia, "Bread, water, and no Ben Ali” adroitly captured the twinned economic and political demands of the movement (Anderson, 2011). In Tunis, "the tone of the protests was rather one of reappropriating patriotic language and symbols: Women and men lay in the streets to spell 'freedom' or 'stop the murders' with their bodies and worked together to tear down and burn the gigantic, Stalin-style portraits of Ben Ali on storefronts and street corners" (Marzouki, 2011). And though the state responded with violence, the call in the crowds of Tahrir Square was typically for salmeya-staying peaceful (Khalil, 2011, p. 1).

On top of these demands for an end to authoritarianism and a turn toward meaningful democracy were the economic and social demands. In Egypt, alongside the popular demand for "Dignity, Democracy, Social Justice" were heard calls for "Bread, Freedom, Social Justice," and most direct, "We Want to Live! We Want to Eat!" (Beinin, 2011, p. 25). Graffiti in Sidi Bouzid, Tunisia, the cradle of the revolution, read "No to youth unemployment," and "No to Poverty" (Knickmeyer, 2011, p. 124). It is no surprise that in the uprising in Sidi Bouzid on December 17, 2010 the words "Employment is a right, you band of thieves!" were heard, an echo of an earlier uprising of miners in 2008, or that the French Revolution's "Liberty, Equality, Fraternity" was transposed into "Work, Liberty, National Dignity" (Achcar, 2012).

A coalition of young people and labour formed the backbone of the Arab Spring. Class and generation combined to create the nucleus of broad popular movements that provided both the numbers and the slogans that animated the political cultures in play. Students, including significant numbers of women, had engaged in anti-Mubarak demonstrations since the early 2000s, and on the day the US launched its invasion of Iraq, March 20, 2003, they and others were numerous enough to break the security force's cordon around Tahrir Square and hold it for several hours, with alternating cries of "Down with America!" and "Down with Mubarak!" (Khalil, 2011, pp. 39-41).

In the summer of 2004, a movement of young leftists proclaiming its message in its name-Kefaya, Enough — emerged to challenge the official elevation of Mubarak's son Gamal as his eventual successor (Khalil, 2011, p. 43ff). It is of interest that the Zapatistas' rallying cry had been "Ya Basta!" (Enough Already) and that the youth movement in Georgia that led the Rose Revolution in November 2003 took the name Kmara! with the same meaning, while the Ukraine's Orange Revolution's youth activists called themselves Pora (It's Time) (Rosenberg, 2011, p. 132).

The core activists and more than 70,000 on-line members of the April 6 movement (the date of a major workers' revolt in 2008) came out of Kefaya and used social media and organizing skills learned in Serbia and elsewhere to facilitate and coordinate actions in Egypt's 18 days of revolt (Rosenberg, 2011, p. 127ff). Young Egyptian activists of the April 6 movement had visited Serbia to learn the techniques of non-violent civil disobedience from the Otpor! (Resistance!) youth movement that helped unseat Slobodan Milošević in October 2000; Otpur! had also helped train the Georgian and Ukrainian groups named above. Serbian youths, in turn, had read the works 
of U.S. political theorist Gene Sharp, steeped in the examples of Gandhi and Martin Luther King, Jr. ${ }^{4}$ They then set up the Center for Applied Nonviolent Action and Strategies (CANVAS) in Belgrade, which trained April 6 activist Mohammad Adel in the summer of 2009. April 6 took Otpor's distinctive clenched fist for their own logo, and carried it into Tahrir Square on their flags in the first days of the uprising (Rosenberg, 2011, p. 141). And just after the events started on January 25, a 26-page pamphlet, widely attributed to April 6, came out, entitled "How to Protest Intelligently" (Rosenberg, 2011, p. 141$)^{5}$

When textile workers at the state-owned Misr Spinning and Weaving Company rose up against the police in Mahalla al-Kubra on April 6, 2008, they were riding a wave of labour actions that had been ongoing since 2004, and gave impetus to a new wave of labour actions in the run-up to 2011 that repudiated the state-controlled unions and forced economic issues such as a minimum wage onto the public stage (Khalil, 2011, pp. 51ff; Mason, 2012, pp. 19-22). Elsewhere, as Gilbert Achcar had observed, "Nobody can ignore the fundamental role played by the Tunisian General Labor Union" (Achcar, 2012).

Mahmoud al-Shaar, who had been a leader at one of the occupied textile factories, said in 2011: "There is a spirit of optimism between all workers, in every sector. During the revolution, we were here from day one. But now it's reached the point where we look around and we recognize these other delegations from the days in Tahrir Square, people from totally different sectors: we know each other's faces, we shake each other's hands, we slap each other on the back" (Mason, 2012, pp. 22-23). One indication of the youth and class composition of the Tahrir demonstrators was provided by a medical volunteer: "Among the dead who fell during the recent demonstrations was found not a single well $\square$ known oppositionist, nor even a known activist. These are young people from disadvantaged neighborhoods, who put themselves on the front lines" (Hennion, 2011, quoted in Anderson, 2011). Nor were all participants from the middle and working classes; inhabitants of Cairo's slums, such as the garbage-pickers (mostly young men and children) of Moquattam, joined in (Mason, 2012, pp. 6-7).

The originality of this approach to overthrowing dictators suggests that yet another path to radical social change has opened up in the twenty-first century: the sustained occupation of public space followed by the struggle for a more open democratic polity, a kind of third way between taking national power through elections and re-making power by wresting communities from neo-liberalism's clutches. As the Arab Spring turns three, the challenge now is to turn the political revolutions into social ones, and for the voices of workers, youth, and women to make themselves heard as they were when bringing down the dictatorships.

Whether the political revolutions in Tunisia, Egypt, and Libya can be pushed further toward social transformation aimed at alleviating crushing poverty and redressing class inequality is an open question. A crucial difference is that the winning political parties in these first elections have 
not voiced the sentiments or responded to the desires of the people who have come out into every capital square, as the mass demonstration that brought about the coup against the Morsi government and the mass demonstrations by Morsi's supporters afterwards showed in 2013. What can be predicted is that their futures depend on the courageous engagement of the social movements and civil society organizations that forced the democratic openings and their ability to shape the direction and composition of the newly elected democratic leadership and parties (in Egypt this has proven extraordinarily difficult, perhaps impossible). And this, in turn, depends on the complex (and undoubtedly long-term) process of forging, sustaining, and reconciling the new political cultures of creation - of democracy, reformist Islam, and popular sovereignty - that brought victory in the first place. Experience, emotions, and idioms all must find organizational expressions equal to this daunting task, or perhaps better put, movements and parties must find a language to bridge their differences.

Occupy Everything. The second half of the year witnessed the rise of an equally improbable challenge at the heart of the system. Occupy Wall Street succeeded against all the historical and cultural odds to electrify ordinary Americans in the fall of 2011. It drew on some of the threads of resistance that we have traced since 1968: discussion-based decision making, occupations of the commons, non- or post-ideological ways of speaking, affinity groups dedicated to addressing particular issues and sustaining the encampmentsin sum, new yet not-so-new ways of doing a creative politics. Its makers tapped the Arab Spring's techniques of struggle and the liberating public festivals of occupation in Spain, the street confrontations and creative actions in austerity-hammered Athens, and the temporary occupations in the English and Chilean student movements over the course of 2010 (among the best of the earliest accounts to date are Mason, 2012; Flank, 2011; Solomon \& Palmieri, 2011; Taylor et al., 2011; van Gelder et al., 2011).

To these, the Occupy movement added its own versions of General Assembly and a brilliant discursive attack on the political and economic elites, seen as "the one percent" responsible for the deteriorating lives of "the ninety-nine percent." The process and the message resonated widely across the US, spreading quickly from New York to other major metropolitan areas (Los Angeles, Boston, Oakland, Chicago, Detroit), smaller cities and towns, and educational institutions such as the University of California. An immense national discussion on the crisis was held, knocking the American political and economic establishments off balance for a time. By mid-autumn, there were occupations in motion across the globe. The system struck back in late fall with a police offensive coordinated by U.S. mayors across the country, using strong arm tactics to force Occupy to abandon most of its public spaces. The movement merged into many smaller, local forms in the course of 2012 (including Occupy the Hood, Occupy Debt, and Occupy Sandy in the wake of the disastrous hurricane of November 2012), with the occupiers discussing and acting on the ways to do this most effectively in the new conjuncture (Schneider, 2012; R. Solnit, 2012, 2013). Sociologist Keith Kahn-Harris 
has termed the movements of 2011as "the movement without a name," the expression of "a trend, a direction, an idea-virus, a meme, a source of energy that can be traced through a large number of spaces and projects. It is also a way of thinking and acting: an agility, an adaptability, a refusal to accept the world as it is, a refusal to get stuck into fixed patterns of thought" (KahnHarris, 2011). In sum, it marked the further growth of political cultures of creation.

\section{Problems and Prospects}

The obvious political question is: Can these new political cultures of opposition produce - or at least contribute to - some type of global transformation of the sort that is needed to deal with a world in crisis? These cases have shown their ability to move beyond ideology in favor of the strengths of popular idioms demanding social justice and have shown us some of the advantages of horizontal networks over vertical hierarchies. But how to fashion largescale popular spaces for democracy, and how to articulate the discourses that will bring together the broadest coalitions ever seen onto a global stage constitute great challenges.

The left has achieved state power in an important set of Latin American countries; does it have the will, internal support, and global room for maneuver to redirect resources to the poorest sectors of society? The experience of Obama and the European Center-Left has shown rather clearly the limited room for maneuver and the dimming prospects for significant reform, domestically or globally, through these parties. The Zapatistas have registered concrete gains on a local level; will they be able to generalize these accomplishments beyond Chiapas? The global justice movement has raised significant opposition to neoliberal globalization. Can this movement, with all the others, reverse the tide of neoliberal capitalism?

As the Zapatistas argue, and the disappointing experience of Lula and the Workers Party in Brazil who watered down their radical program once in power has shown, elections are not a magic solution to undoing fundamental structures of exploitation. This should be a continuing task for the post-Arab Spring decade that is underway. But neither is direct democracy a panacea, as the Zapatistas' containment in Chiapas and the dispersal of Occupy suggest. And yet, the capacity to re-occupy public space is crucial for the long-term success of the Arab Spring, as the vigorous protests which culminated in the coup against President Mohammad Morsi in Egypt and the flash uprisings in Turkey and Brazil reminded us in the summer of 2013.

What, then, lies between or beyond direct action and elections? One idea is to combine electing "progressive" governments and forging social movements to push them from below and beside to make good on their promises, and to make links with other movements, nations, and organizations everywhere. In other words, rather than the dichotomous choice between seeking to change the world through elections versus building a new society from the bottom 
up, the future of radical social change may well lie at the many possible intersections of deeply democratic social movements and equally diverse and committed new parties and political coalitions. The Pink Tide is already working near this intersection. Other struggles that point toward this include the long movement for radical reforms in Kerala, India, the experiences of the world's Green parties, the political movement that grew up in Iceland after the great crash of 2008, and the global climate justice movement.

In Kerala, for example, a series of elected, non-charismatic (in a positive sense) left-of-center governments over the past fifty years have raised the quality of life - whether measured by nutrition, health, life span, access to food and shelter, and literacy education - to standards that are superior to elsewhere in India and would be the object of envy in most of the world. They have done this despite a lack of monetary resources, a low per capita GNP, and even with deep structural unemployment, because they have been pushed from below by strong, independent social movements in civil society of workers, women, and lower castes. This synergetic relationship has succeeded in forging and maintaining relatively equitable, more participatory conditions of life for the more than 30 million people who live there, even in periods when the left has not been in power (Franke \& Chasin, 1994, Heller, 1999).

The world's Green parties also embody a new political culture of creation, sometimes themselves acting to bridge the divide between those who seek to take state power and those who seek to transform the very nature of power. Though far from power in many places - notably the US and UKand having made truly invidious compromises when in government as in Germany (Jachnow, 2013), they also hint at the powerful combination of social movement dynamism from below and a new kind of party organization. Moreover, they are transnational in vision and organization in a way that other parties, including those on the left, are not.

Iceland undertook a hopeful political experiment dubbed the "Saucepan Revolution" when the raucous banging of pots and pans in popular street protests in January 2009 forced the right-of-center government responsible for the precipitous collapse of Iceland's banks to yield power to a new governing coalition of socialists, democrats, greens, and the left, who were affirmed in a general election in April 2009. In the face of a horrific economic crisis, the creative actions of the Left-Green Movement and Social Democratic Alliance government, and the many networks that pressure and support them, produced solutions such as the 2009 referendum in which 98 percent of the population rejected the previous government's agreement to repay the foreign debt of the failed banks, another indication of this new political culture (Chataigne 2009; Krugman, 2011; Júlíusson \& Helgason, 2013; Magnason, 2008; R. Solnit, 2008; Wade \& Sigurgeirsdottir, 2010). The fragility of the new situation was laid bare in the April 2013 elections which returned the center-right to power.

2011 ended with the impact of Occupy on the UN climate negotiations in Durban, South Africa, carried forward again at the end of 2012 in Doha, 
Qatar. The negotiations themselves produced the expected non-ambition and irresponsible delay, but a growing coalition of progressive countries inside the negotiations, young activists who raised their voices and built their own strong ties, and the global climate justice organizations that stood and sat with them in an occupation of the corridors and streets worked together to deliver a rather different outcome from the triumphalist official one or the pessimistic verdict of some movement leaders (Foran \& Widick, 2013). The actions and communication processes established between the state actors inside and the social movements outside continue to work together for a fair and binding treaty to lower greenhouse gas emissions, perhaps the most pressing issue of our time.

\section{Conclusions}

It is entirely possible that the future of radical social change lies at the various intersections of deeply democratic social movements and equally diverse and committed political coalitions. Hamid Dabashi, the first great theorist of the Arab Spring, proposes that we consider the events a new kind of "openended" revolution.

That ever-expanding public space and political participation are precisely what inform my idea of open-ended revolution, in which the distinction no longer exists between the French [Revolution's] (social) and American [Revolution's] (political) model, in Arendt's terms. But in fact the fusion of the two will have created a third model, closer to what Trotsky meant by "permanent revolution" (and that we hear in the Egyptian slogan al-Thwarah al-Mustamarrah), but this time in a more gradual, systematic, and grounded manner in which not just the working class but also women and students - that is, the two social formations that expand the economic into public space-will be integral to the revolutionary unfolding. (Dabashi, 2012, p. 247)

It will take time for these open-ended revolutions to blossom and reach their full potential. Important to this process will be the articulation of powerful political cultures based on participatory (not formal, representative, elitecontrolled) democracy and on economic alternatives that challenge the neoliberal capitalist globalization that created the conditions for their flowering in the first place - namely, political cultures of creation as well as opposition.

The people in each of these places - the most radical ones, the younger ones, the most savvy - rejected the dysfunctional social and political systems they had inherited. They were not about renegotiating anybody's ruling bargain. And they succeeded. Or at least they haven't failed. And, like their counterparts everywhere, they are not done yet. 


\section{Notes}

1 This essay draws substantially on its older sister, "Global affinities: The new cultures of resistance behind the Arab Spring," forthcoming in Kamrava.

2 In Anna Karenina, Tolstoy's protagonist asks "What is to be done? What is to be done? What's the best way to act in this terrible situation? - that's what we must think about": see The New York Times Magazine (December 23, 2012), 46.

3 In fact, "between January 3 and April 12, 2003, 36 million people across the globe took part in almost 3,000 protests against the Iraq war" according to French academic Dominique Reynié (cited in Callinicos 2005).

4 Amazon's webpage asserts that "From dictatorship to democracy was a pamphlet, printed and distributed by Dr Gene Sharp and based on his study, over a period of forty years, on non-violent methods of demonstration. Now in its fourth edition, it was originally handed out by the Albert Einstein Institution, and although never actively promoted, to date it has been translated into thirty-one languages. This astonishing book travelled as a photocopied pamphlet from Burma to Indonesia, Serbia and most recently Egypt, Tunisia and Syria, with dissent in China also reported. Surreptitiously handed out amongst youth uprisings the world over - how the 'how-to' guide came about and its role in the recent Arab uprisings is an extraordinary tale":http://www. amazon.com/Dictatorship-Democracy-Gene-Sharp/dp/1846688396/ref=sr_1_1?s=bo oks\&ie=UTF8\&qid $=1355440345 \&$ sr $=1-1 \&$ keywords $=$ Gene+Sharp April $\overline{6}$ compiled its own manual based on a range of sources and members' own experiences (Ishani 2011, 144). For a trenchant critique of the politics of April 6, see Roberts 2013.

5 It is true that Otpor took money from, among others, rightwing and counterrevolutionary democracy-promoting institutions like the notorious National Endowment for Democracy in the United States, and that the Einstein Institution had similar links, as my reviewer pointed out to me. Likewise, among the funders of CANVAS are to be found Freedom House. That this makes them guilty of being "in the service of imperial projects" (see Barker 2011), is, I feel, a stretch too far.

\section{References}

Adbusters. (2011, July 11). “\#OCCUPYWALLSTREET: A shift in revolutionary tactics.” Retrieved from https://www.adbusters.org/blogs/adbusters-blog/occupywallstreet.html

Anderson, K. (2011). Arab revolutions at the crossroads. April 2. Retrieved from http://www. internationalmarxisthumanist.org/articles/arab-revolutions-crossroads-kevin-anderson

Anderson, K. (2012, Spring-Summer). Year two of the Arab revolutions. Logos. Retrieved from http://logosjournal.com/2012/spring-summer_anderson/

Achcar, G. (2012, January). The Bouazizi spark: The beginning of a long revolutionary process. Retrieved from http://english.al-akhbar.com/content/bouazizi-spark-beginning-longrevolutionary-process

Beinin, J. (2011, September 12). Working-class revolutions? The Nation, 26-27.

Big Noise. (1998). Zapatista. Santa Barbara: Big Noise Films. Retrieved from www.bignoisefilms. com

Callinicos, A. (2005). Anti-war protests do makea difference. Socialist Worker(March 19). Retrieved from http://en.wikipedia.org/wiki/Protests_against_the_Iraq_War\#March_20.2C_2003

Chataigne, C. (2009, March). Iceland and the Saucepan Revolution. Socialist Review. Retrieved from http://www.socialistreview.org.uk/article.php?articlenumber=10735

Chomsky, N. (2012). Occupy. Brooklyn: Zuccotti Park Press.

Conant, J. (2010). The Poetics of Resistance: The Revolutionary Public Relations of the Zapatista Insurgency. Oakland: AK Press.

Cooper, M. (2001). Pinochet and me. London: Verso.

Dabashi, H. (2012). The Arab Spring: The end of postcolonialism. London: Zed.

Dellacioppa, K. (2009). This bridge called Zapatismo: Building alternative political cultures in Los Angeles, Mexico City, and beyond. Lanham, MD: Lexington Books.

Dieterich, H. (2006). Communitarian Socialism, and the Regional Power Block. MRZine. 
Retrieved from http://mrzine.monthlyreview.org/dieterich070106.html

EZLN [Zapatista Army of National Liberation]. (2002). Second declaration from the Lacandón Jungle: 'Today we say: We will not surrender!' In Tom Hayden (Ed.), The Zapatista reader (pp. 221-31). New York: Thunder's Mouth Press and Nation Books.

Flank, L. (Ed.). (2011). Voices from the 99 percent: An oral history of the Occupy Wall Street movement. St Petersburg, FL: Red and Black Publishers.

Foran, J. (2005). Taking power: On the origins of Third World revolutions. Cambridge: Cambridge University Press.

Foran, J. (2013, July 31). Not yet the end of the world: Political cultures of creation and the global youth climate justice movement. Talk given at the University of Waikato, Hamilton, New Zealand.

Foran, J. (forthcoming). Global affinities: The new cultures of resistance behind the Arab Spring. In M. Kamrava (Ed.), The evolving ruling bargain in the Middle East. London: Hurst Publishers, and Oxford: Oxford University Press.

Foran, J. \& Widick, R. (2013, May). Breaking the climate deadlock. Contexts: a Journal of the American Sociological Association (12.2), 34-39.

Franke, R. \& Chasin, B. (1994). Kerala: Radical reform as development in an Indian state. San Francisco: The Institute for Food and Development Policy.

Gelvin, J. (2012). The Arab uprisings: What everyone needs to know. Oxford: Oxford University Press.

Goldstone, J. (2011). Understanding the revolutions of 2011: Weakness and resilience in Middle Eastern autocracies. In Council on Foreign Relations (Ed.), The new Arab revolt (pp. 8-16). New York: Council on Foreign Relations.

Gunderson, C. (2013). The Provocative Cocktail: Intellectual Origins of the Zapatista Uprising, 1960-1994. Ph.D. dissertation, Department of Sociology, New York University.

Heller, P. (1999). The labor of development: Workers and the transformation of capitalism in Kerala, India. Ithaca: Cornell University Press.

Hennion, C. (2011, February 2). Au Caire, une foule de manifestants de tous horizons en quête de port-parole. Le Monde.

Holloway, J. (2002). Change the world without taking power: The meaning of revolution today. London: Pluto Press.

Ishani, M. (2011). The hopeful network. In Council on Foreign Relations (Ed.), The new Arab revolt (pp. 143-48). New York: Council on Foreign Relations.

Jachnow, J. (2013). Green trajectories. New Left Review (81) (May/June), 95-117.

Júlíusson, A. \& Helgason, M. (2013). The roots of the Saucepan Revolution in Iceland. In Bron Taylor, Nina Witoszek and LarsTrägårdh (Eds.), Civil Society in the Age of Monitory Democracy (pp. 189-201). Oxford: Berghahn Books.

Kahn-Harris, K. (2011, June 22). Naming the movement. openDemocracy.net.

Kamrava, M. (Ed.) (forthcoming). The evolving ruling bargain in the Middle East. Oxford: Oxford University Press.

Khalil, A. (2011). Liberation square: Inside the Egyptian Revolution and the rebirth of a nation. New York: St. Martin's.

Knickmeyer, E. The Arab world's youth army. In Council on Foreign Relations (Ed.), The new Arab revolt (pp.122-26). New York: Council on Foreign Relations.

Krugman, P. (2011, October 27). The path not taken. New York Times. Retrieved from http:// www.nytimes.com/2011/10/28/opinion/krugman-the-path-not-taken.html

Labro P. and the staff of Edition Special. (1969). This is only a beginning. New York: Funk \& Wagnalls.

Magnason, A. (2008). Dreamland: A self-help manual. London: Citizen-Press.

Manrique, J. (2006, July 26). Bolivia: Evo's friends and foes. Latinamerica Press (14), 8-9.

Marzouki, N. (2011, January 19). Tunisia's wall has fallen. MERIP (Middle East Research and Information Project) Reports. Retrieved from http://www.merip.org/mero/mero011911

Mason, P. (2012). Why it's still kicking off everywhere: The new global revolutions. London: Verso.

Morales, E. (2007). Bolivian President Evo Morales on indigenous rights, climate change, establishing diplomatic relations with Iran, Che Guevara's legacy and more. Democracy Now! (September 26). Retrieved from http://www.democracynow.org/2007/9/26/bolivian_ president_evo_morales_on_indigenous

Nichols, J. (2012). Uprising: How Wisconsin renewed the politics of protest, from Madison to Wall 
Street. New York: Nation Books.

Parenti, C. (2005). Bolivia's battle of wills. The Nation (July 4), 13-18.

Parenti, C. (2011, July 19). Reading the world In a loaf of bread -- soaring food prices, wild weather, upheaval, and a planetful of trouble. Retrieved from http://www.tomdispatch.com/ archive/175419

Polletta, F. (2002). Freedom is an Endless Meeting: Democracy in American Social Movements. Chicago: University of Chicago Press.

Poster, M. (1975). Existential Marxism in postwar France: From Sartre to Althusser. Princeton: Princeton University Press.

Ripper, V. (Director). (2013). Occupy Love. Canada: Canadian Media Fund.

Roberts, H. (2013). The Revolution that Wasn't. London Review of Books, 35(17) (September 12), 3-9. Retrieved from http://www.lrb.co.uk/v35/n17/hugh-roberts/the-revolution-thatwasnt

Rosenberg, T. (2011). Revolution U. In Council on Foreign Relations (Ed.), The new Arab revolt (pp. 27-42). New York: Council on Foreign Relations.

Schneider, N. (2012, September 24). Occupy, after Occupy. Retrieved from http://www. thenation.com/article/169761/occupy-after-occupy

Shadid, A. (2006). Night draws near: Iraq's people in the shadow of America's war. New York: Picador.

Sitrin, M. (2006). Horizontalism: Voices of Popular Power in Argentina. Oakland: AK Press.

Sitrin, M. (2012). Everyday Revolutions: Horizontalism and Autonomy in Argentina. London: Zed.

Solnit, D. (2004a). The new radicalism. Interview with Rachel Neumann, AlterNet. Retrieved from http://www.alternet.org/story/19308/the_new_radicalism

Solnit, D. (2004b). Introduction: The new radicalism: Uprooting the system and building a better world. In David Solnit (Ed.), Globalize liberation: How to uproot the system and build a better world, xi-xxiv. San Francisco: City Lights Books.

Solnit, R. (2008, October). News from nowhere: Iceland's polite dystopia. Harper's Magazine. Retrieved from http://harpers.org/archive/2008/10/news-from-nowhere/

Solnit, R. (2012, December 23). The sky's the limit: The demanding gifts of 2012. Retrieved from http://www.tomdispatch.com/post/175632/tomgram\%3A_rebecca_solnit,_2013_as_year_ zero_for_us_-- and_our_planet/

Solnit, $\bar{R} .(\overline{2013}, \bar{M}$ ay 19$)$. Too soon to tell: The case for hope, continued. Retrieved from http:// www.tomdispatch.com/post/175701/tomgram\%3A_rebecca_solnit,_what_comes_after_ hope

Solomon, C. \& Palmieri, T. (Eds.) (2011). Springtime: The new student rebellions. London: Verso.

Spence, J. (1978). Class mobilization and conflict in Allende's Chile: A review essay. Politics \& Society (8.2), 131-64

Taylor, A. et al. (Eds.). (2011). Occupy! Scenes from occupied America. London: Verso.

Valenzuela, A. (1979). The breakdown of democratic regimes: Chile. Baltimore: Johns Hopkins. van Gelder, S. and the staff of YES! Magazine. (Eds.). (2011). This changes everything: Occupy Wall Street and the 99\% movement. San Francisco: Berrett-Koehler Publishers.

Wade, R. \& Sigurgeirsdottir, S. (2010, September-October). Lessons for Iceland. New Left Review (65), 5-29.

Wallerstein, I. (2011, November 4). The contradictions of the Arab Spring. al-Jazeera. Retrieved from http://www.aljazeera.com/indepth/opinion/2011/11/20111111101711539134.html

Zibechi, R. (2010). Dispersing Power: Social Movements as Anti-State Forces. Oakland: AK Press. 